\title{
REVISED Soluble nitrogen forms in sand soil of Pallag: a
}

\section{quantitative report [version 2; peer review: 3 approved]}

\author{
Ida Kincses ${ }^{1}$, Jesus R. Melendez (D)2,3, Lenin Ramírez-Cando4, \\ Diego Burbano-Salas (i)5, Daniel A. Lowy 2,6, Gerardo Cuenca Nevarez7, \\ Viviana Talledo Solórzano7 , Juan Morales Arteaga8, Benito Mendoza (iD9, \\ Zsolt Sándor (iD1,2
}

\footnotetext{
${ }^{1}$ Institute of Agrochemistry and Soil Science, University of Debrecen, Debrecen, Hungary

${ }^{2}$ Research Group of Applied Plant Glycobiology, Dama Research Center limited, Kowloon, Hong Kong

${ }^{3}$ Facultad Educación Técnica para el Desarrollo, Universidad Católica de Santiago de Guayaquil, Guayaquil, Ecuador

${ }^{4}$ School of Biological Sciences and Engineering, Yachay Tech University, Hda. San José s/n y Proyecto Yachay, Urcuquí, Ecuador

${ }^{5}$ Carrera de Ingenería Ambiental, Escuela Superior Politécnica de Chimborazo, Riobamba, Ecuador

6VALOR HUNGARIAE Ltd, Budapest, Hungary

${ }^{7}$ Facultad de Ciencias Zootécnicas, Universidad Técnica de Manabí, Avenida Jose Maria Urbina, Portoviejo, Ecuador

${ }^{8}$ Biotechnical Faculty, University of Ljubljana, Ljubjlana, Slovenia

${ }^{9}$ Universidad Nacional de Chimborazo, Riobamba, Ecuador
}

V2 First published: $28 \mathrm{Jul}$ 2020, 9:781

https://doi.org/10.12688/f1000research.25260.1

Latest published: 07 Oct 2020, 9:781

https://doi.org/10.12688/f1000research.25260.2

\section{Abstract}

Nitrogen $(\mathrm{N})$ is a crop macronutrient of major importance, which affects both plant growth and yield. In this paper we discuss the humus content (\%) and various soluble $\mathrm{N}$ forms $\left(\mathrm{NO}_{3}{ }^{-}\right.$, total $\mathrm{N}$, nitrate$\mathrm{N}$, ammonium- $\mathrm{N}$, and organic nitrogen) available in humus sand soil samples originating from the Pallag Experimental Station of Horticulture at the University of Debrecen, Hungary. We found $45.4 \%$ nitrate- $\mathrm{N}$ and $13.8 \%$ nitrite- $\mathrm{N}$ of total $\mathrm{N}$ content present in the soil. Considering the percentage distribution of soluble $\mathrm{N}$ forms present at the Pallag Experimental Station, we recommend using this soil in further pot experiments, given that this has optimal nutrient supply capacity. In addition, we examined possible statistical correlations between humus\% and $\mathrm{N}$ forms.

\section{Keywords}

pot experiment, total $\mathrm{N}$, nitrate, nitrite, ammonium, nutrient supply capacity

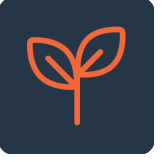

This article is included in the Agriculture, Food and Nutrition gateway.

\begin{tabular}{|c|c|c|c|}
\hline \multicolumn{4}{|c|}{ Open Peer Review } \\
\hline \multicolumn{4}{|c|}{ Approval Status $\checkmark$} \\
\hline & 1 & 2 & 3 \\
\hline \multirow{4}{*}{$\begin{array}{l}\text { version } 2 \\
\text { (revision) } \\
07 \text { Oct } 2020\end{array}$} & & & \\
\hline & $\checkmark$ & & $\checkmark$ \\
\hline & view & $\checkmark$ & view \\
\hline & a & $\mathrm{s}$ & a \\
\hline version 1 & $?$ & $?$ & $?$ \\
\hline 28 Jul 2020 & view & view & view \\
\hline
\end{tabular}

1. Katalin Juhos, Szent István University, Budapest, Hungary

2. Yuhua Kong, Henan Agricultural University, Zhengzhou, China

3. Paul S. Agachi, Botswana International University of Science and Technology, Palapye, Botswana

Any reports and responses or comments on the article can be found at the end of the article. 
Corresponding authors: Ida Kincses (kincsesi@agr.unideb.hu), Zsolt Sándor (sandor@edu.damaresearch.com)

Author roles: Kincses I: Conceptualization, Data Curation, Investigation, Methodology, Project Administration, Supervision, Visualization, Writing - Original Draft Preparation, Writing - Review \& Editing; Melendez JR: Investigation, Methodology, Project Administration, Writing - Original Draft Preparation; Ramírez-Cando L: Data Curation, Methodology, Writing - Original Draft Preparation; Burbano-Salas D: Data Curation, Methodology, Writing - Review \& Editing; Lowy DA: Methodology, Project Administration, Writing - Original Draft Preparation, Writing - Review \& Editing; Cuenca Nevarez G: Investigation, Methodology, Writing - Original Draft Preparation; Talledo Solórzano V: Investigation, Methodology, Writing - Original Draft Preparation, Writing - Review \& Editing; Morales Arteaga J: Data Curation, Investigation, Methodology, Project Administration, Writing - Original Draft Preparation; Mendoza B: Investigation, Methodology, Writing - Original Draft Preparation, Writing - Review \& Editing; Sándor Z: Conceptualization, Data Curation, Formal Analysis, Investigation, Methodology, Project Administration, Supervision, Visualization, Writing - Original Draft Preparation, Writing - Review \& Editing

Competing interests: No competing interests were disclosed.

Grant information: This work was supported by Dama Research Center limited.

Copyright: ( 2020 Kincses I et al. This is an open access article distributed under the terms of the Creative Commons Attribution License , which permits unrestricted use, distribution, and reproduction in any medium, provided the original work is properly cited.

How to cite this article: Kincses I, Melendez JR, Ramírez-Cando L et al. Soluble nitrogen forms in sand soil of Pallag: a quantitative report [version 2; peer review: 3 approved] F1000Research 2020, 9:781 https://doi.org/10.12688/f1000research.25260.2

First published: 28 Jul 2020, 9:781 https://doi.org/10.12688/f1000research.25260.1 


\section{REVISED Amendments from Version 1}

In the second version of our manuscript we have made the following changes:

We clarified the land-use type from where the samples originated, as requested by Yuhua, K. and Juhos, K.; we added the meanings of "control", "greenhouse", and "pollutant nitrogen" (i.e., nitrite) as suggested by Juhos, $\mathrm{K}$.

Regarding conclusions about the test soil suitable for use, there was a misunderstanding, so we tried to clarify in the text, as well; we meant that test soil could be used in pot experiments, according to its characteristics described in the study, which seemed to be confirmed by the total element contribution in test plant (tomato). The latter is the topic of our forthcoming study (we do not present these results here).

We clarified the soil-solution ratio.

We agree with Juhos, K.'s comments that collecting soil samples from various depths is very important to better understand $\mathrm{N}$ transformation and mobility in soil. Nevertheless, in the present study we aimed to analyze whether this soil is suitable or not for tomato pot experiments.

In addition, we updated Table 1 according to comments made by Juhos, K. and Yuhua, K.

Regarding Yuhua, K.'s last comment: we found statistical correlation between humus\% and ammonium- $\mathrm{N}(\mathrm{mg} / \mathrm{kg})$ only, as stated at Results and Discussion. This is the reason why we did not display correlations between humus and other $\mathrm{N}$ forms.

Equations E1 and E2 were revised and explained, as requested by Professor Agachi, $\mathrm{S}$.

Any further responses from the reviewers can be found at the end of the article

\section{Introduction}

Nitrogen $(\mathrm{N})$ is an essential element for plants, takes various forms in soil ${ }^{1}$, and is one of the most limiting nutrients for various crops $^{2-4}$. Nitrogen is present in soils as inorganic nitrogen (nitrate, ammonium, and dinitrogen) and organic nitrogen (urea and amino acids) $)^{5}$.

Conversions between organic and mineral $\mathrm{N}$ forms are primarily affected by soil microorganisms, which enable conversion to forms that plants can uptake ${ }^{6}$. In addition, some pollutant $\mathrm{N}$ forms (e.g., nitrite) are present in soil, so nitrogen conversions may indirectly affect human health and load the environment ${ }^{1}$. For this reason, quantifying studies aim to better understand nitrogen form ratios in soil and contribute to reaching sustainable agriculture practice. Recently, Jakab published a similar study $^{7}$ quantifying another vital element for plants, phosphorus, in soil from the same region.

Humus is a main fertility component of the soil, $65-75 \%$ of its structure being made up of organic matter ${ }^{8,9}$. We decided to include humus content in this N-related study as it represents a known indicator of soil quality ${ }^{10}$.

Calcium chloride $\left(\mathrm{CaCl}_{2}\right)$-soluble nitrogen forms are the most available $\mathrm{N}$ ions for assimilation by plants $^{11,12}$. Therefore, we quantified all $\mathrm{N}$ forms in $\mathrm{CaCl}_{2}$ solution. Additionally, we determined nitrate- $\mathrm{N}$ via a potassium chloride $(\mathrm{KCl})$-based method.

The main objectives of our study were: (a) to map out all easily absorbed nitrogen forms for better understanding of available nutrient composition and (b) to determine the ratio of pollutant (nitrite) and absorbable (ammonium ion, nitrate) $\mathrm{N}$ forms in humus sand soil in pot experiments.

\section{Methods}

Randomized soil sampling, approx. $60 \mathrm{~kg}$; 15 cores from control parcel (no fertilizer was applied, nor crop production, or land-use), was done at the Pallag Experimental Station of Horticulture at the University of Debrecen, Hungary on May 20, 2020, according to Hungarian national standard MSZ $080202^{13}$ from the $-20 \mathrm{~cm}$ of topsoil using a vane. On other parcels (different from control parcels), orchards are being cultivated. Sampling point is located on a moderately hot and dry micro-region, the average annual temperature varies between $9.7-10.0^{\circ} \mathrm{C}$. The annual precipitation is of only 520-550 $\mathrm{mm}^{14}$. Next, samples were transferred for measurements to a greenhouse (where pots had been placed for pot experiments); the greenhouse was located at Department of Agriculture, at the University of Debrecen. To measure chemical parameters, samples were sieved through a $2 \mathrm{~mm}$ mesh.

We determined soil moisture content gravimetrically, according to Klimes-Szmik ${ }^{15}$, drying the soil samples at $105^{\circ} \mathrm{C}$ for $24 \mathrm{~h}$ and weighing the mass loss. To evaluate texture, Arany-type plasticity index was measured, using the methodology recommended by Hungarian national standard MSZ-08 0206/1-78 ${ }^{16}$; briefly from a burette distilled water is added to $100 \mathrm{~g}$ sample until soil reaches the upper limit of its water holding capacity. Soil $\mathrm{pH}$ was determined in $1 \mathrm{~mol} \mathrm{~L}^{-1} \mathrm{KCl}$ solution (soil/ water $=1.0 / 2.5$ wt./wt.), according to Buzás ${ }^{17}$ using a glass electrode (Model Seven2Go Advanced Single-Channel Portable $\mathrm{pH}$ Meter, Mettler, Toledo. We first determined organic-C\%. content with potassium dichromate, according to Székely ${ }^{18}$, and than we calculated humus\% from organic-C\% according to: the Hungarian standard MSZ-08 $0210-77^{19}$ (E2); briefly, 10 $\mathrm{mL} \mathrm{K}$-dichromate was added to $1.0 \mathrm{~g}$ of soil sample (solution/ soil=10/1) in a $300 \mathrm{~mL}$ Erlenmeyer flask, then $0.10 \mathrm{~g} \mathrm{Ag}_{2} \mathrm{SO}_{4}$ aqueous solution was added, boiled for 5 minutes, cooled to room temperature, and titrated with $0.2 \mathrm{~N}$ Mohr's salt solution. Ferroin was used was the indicator, given that its color change is reversible, pronounced, and fast. We calculated $\mathrm{C} \%$ according to Equation (E1):

$$
C \%=\frac{a * 0.0006 * 100}{b}
$$

where $a$ is the volume difference (Mohr's salt solution loss) between blank and soil sample titration (expressed in $\mathrm{mL}$ ), multiplied by the Mohr-salt factor (which is 0.0006) and b represents the weight of the soil sample $(\mathrm{g})$, multipled with 100 to convert results to percentage. 
Next, humus\% was calculated according to Equation (E2):

$$
\operatorname{Humus}(\%)=C(\%) * 1.724
$$

Where $\mathrm{C}(\%)$ is organic-Carbon (expressed in percentage), 1.724 is a multiplication factor which was determined by the Hungarian standard MSZ-08 0210-77 based on a number of experimental results; it was concluded that Humus(\%) values can be calculated from organic- $\mathrm{C} \%$ with high reliability.

All measurements of soluble $\mathrm{N}$ forms in soil were conducted according to Hungarian standard MSZ 20135:1999²0; briefly, to determine $\mathrm{KCl}-\mathrm{NO}_{3}(\mathrm{mg} / \mathrm{kg})$ content, the sample was prepared with $1 \mathrm{~mol} \mathrm{~L}^{-1} \mathrm{KCl}$ of soil solution $(74.5 \mathrm{~g} \mathrm{KCl}$ were added to $1 \mathrm{~L}$ distilled water ${ }^{21}$. Spectra were recorded with a Model PU 8610 UV/VIS kinetics spectrophotometer by Pye Unicam (Cambridge, GB). For assessing total soluble nitrogen (UV degraded) content, soil samples were extracted with $0.01 \mathrm{~mol} \mathrm{~L}^{-1} \mathrm{CaCl}_{2}$ solution. Soil samples were mixed with sodium tetraborate buffer, then oxidized with excess $\mathrm{K}_{2} \mathrm{~S}_{2} \mathrm{O}_{8}$ and passed into an ultraviolet digester. Nitrate was reduced on a cadmium-copper column and then converted to a colored azo compound via the Griess-Ilosvay reaction; dissolving $0.50 \mathrm{~g}$ of sulfanilic acid and $0.05 \mathrm{~g}$ of 1-naphthylamine in $150 \mathrm{~mL}$ of dilute acetic acid. A colored solution was obtained, which was analyzed by visible photometry at $540 \mathrm{~nm}$ (SKALAR photometry (San Plus Analyser, S.F.A.S).

We determined $\mathrm{CaCl}_{2}$-ammonium-N (mg/kg) using a modified Berthelot reaction-based method in which ammonia was initially converted to monochloramine and then to 5-aminosalicylate, according to Buzás ${ }^{17}$ using 1\% EDTA solution and $1 \mathrm{ml} 0.06 \mathrm{~N}$ $\mathrm{NaOH}$. After oxidation, a green color complex was obtained, with a maximum light absorption at $660 \mathrm{~nm}$. Nitrate-N was determined as described above for the measurement of $\mathrm{N}$ content (after reduction, conversion to azo dye, and photometric measurement at $540 \mathrm{~nm}$ ). All soluble forms were detected by SKALAR photometry (San Plus Analyser, S.F.A.S) in a segmented continuous flow (SCF) system. Finally, we calculated nitrite-N (mg/kg) using Equation (E3), proposed by Buzás ${ }^{17}$ :

$$
\text { OrganicN }=\text { Total } N-\text { ammonium } N-(\text { nitrate } N+\text { nitrite })
$$

To better understand the correlation between humus\% (Y) and $\mathrm{N}$-forms (X), we carried out two different tests (i) the Pearson test to establish the relation between the variance $(\mathrm{Y})$ and covariance (XY); and (ii) the Kendall test to verify whether the two variables may be regarded as statistically dependent. All statistical analysis was performed with $\mathrm{R}$ Statistical Software 3.5.1 (Foundation for Statistical Computing, Vienna, Austria).

\section{Results}

Soil $\mathrm{pH}$ was slightly acidic: $\mathrm{pH}(\mathrm{KCl}) 5.5$. As $\mathrm{K}_{\mathrm{A}}=30$, according to Arany the soil is considered humus sand ${ }^{18}$. For these samples, $1.4 \%$ humus content was found, which represents a reasonable value for a sand soil $^{18}$. Nitrate content was determined using two methods: $\mathrm{KCl}-\mathrm{NO}_{3}(12.66 \mathrm{mg} / \mathrm{kg})$ and $\mathrm{CaCl}_{2}-\mathrm{NO}_{3}(13.53$ $\mathrm{mg} / \mathrm{kg}$ ), and the average value of nitrate content $(12.48 \mathrm{mg} / \mathrm{kg})$ served for the calculation of percentages in Figure 1.

Average ammonium- $\mathrm{N}$ was $6.8 \mathrm{mg} / \mathrm{kg}$, which represents $24.7 \%$ of the total-N content. In addition, $3.8 \mathrm{mg} / \mathrm{kg}$ of nitrite- $\mathrm{N}$ (pollutant nitrogen form) was assessed and found to be one order of magnitude less than the nitrate- $\mathrm{N}$ content, as expected for well-ventilated sand soil. Organic-N of $4.4 \mathrm{mg} / \mathrm{kg}$ contributed by $16.1 \%$ to the total nitrogen content of soil (Table 1 ).

Considering all forms of $\mathrm{N}$ under study, the results of correlation analysis evidenced that only the ammonium- $\mathrm{N}$ form was in strong correlation with humus\%, with $\mathrm{r} \approx 0.97$ and $\mathrm{T} \approx 0.99$ (Figure 2 ).

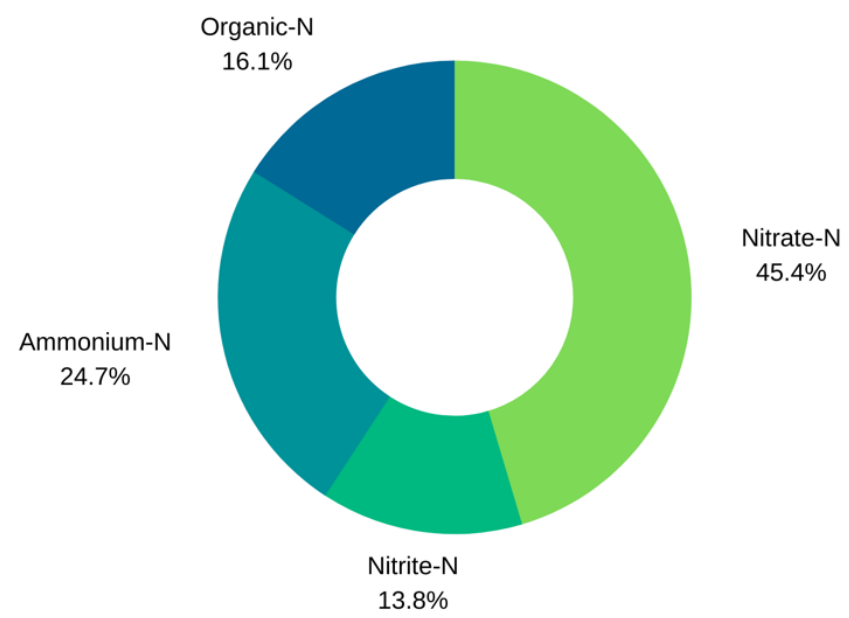

Figure 1. Percentage distribution of the soluble forms of nitrogen present in soil.

Table 1. Average values of humus\%, and soluble $\mathbf{N}$ forms.

\begin{tabular}{|l|c|c|c|c|c|c|}
\hline & Humus \% & \multicolumn{5}{|c|}{$\mathbf{N}$ forms (mg/kg) } \\
\hline & & Nitrate-N & Ammonium-N & Nitrite-N & Organic-N & Total-N \\
\hline ID & 1 & 2 & 3 & 4 & 5 & 6 \\
\hline avg Result & 1.4 & 12.5 & 6.8 & 3.8 & 4.4 & 27.5 \\
\hline SD & 0.15 & 0.075 & 0.02 & derived & 0.15 & 0.05 \\
\hline
\end{tabular}




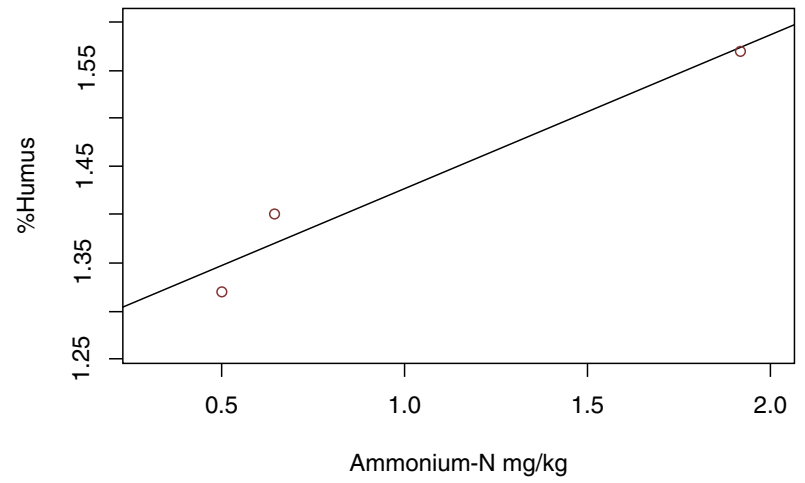

Figure 2. Correlation between humus\% and ammonium-N (mg/kg).

These promising initial results call for additional experiments to confirm the strong correlation between these two variables. Total-N also showed a good correlation with humus\%; however, it was not as strong as that found between humus\% and ammonium-N.

\section{Conclusions}

Our results reveal that the ratio of nitrate-N and nitrite-N (which is determined mostly by soil oxidation-reduction conditions) is optimal in sand soil samples originating from the Pallag Experimental Station of Horticulture at the University of Debrecen, Hungary. Based on the percentage distribution of soluble $\mathrm{N}$ forms present at Pallag Experimental Station, authors recommend using this soil in further pot experiments, given the soil's optimal nutrient supply capacity ${ }^{21}$.

\section{Data availability}

Underlying data

Figshare: Supporting data - N forms and Humus\% in Sand soil, Nyírség. https://doi.org/10.6084/m9.figshare.12581303.v322

Data are available under the terms of the Creative Commons Attribution 4.0 International license (CC-BY 4.0).
1. Robertson GP, Groffman PM: 13 - NITROGEN TRANSFORMATIONS (E. A. B. T.-S. M. PAUL Ecology and Biochemistry. (Third Edition) (ed.); 2007; 341-364. Publisher Full Text

2. Nascente AS, Kluthcouski J, Crusciol CAC, et al.: Fertilization of common bean cultivars in tropical lowlands. Pesquisa Agropecuária Tropical. 2012; 42(4): 407-415.

Publisher Full Text

3. Nascente AS, Carvalho, MDS, Melo LC, et al.: Nitrogen management effects on soil mineral nitrogen, plant nutrition and yield of super early cycle common bean genotypes. Acta Scientiarum Agronomy. 2017; 39(3): 369-378. Publisher Full Text

4. Bloom AJ, Jackson LE, Smart DR: Root growth as a function of ammonium and nitrate in the root zone. Plant Cell Environ. 1993; 16(2): 199-206. Publisher Full Text

5. Crawford NM, Glass ADM: Molecular and physiological aspects of nitrate uptake in plants. Trends Plant Sci. 1998; 3(10): 389-395. Publisher Full Text

6. Schimel JP, Bennett J: Nitrogen mineralization: challenges of a changing paradigm. Ecology. 2004; 85(3): 591-602.

Publisher Full Text

7. Jakab A: The ammonium lactate soluble potassium and phosphorus content of the soils of north-east Hungary region: a quantifying study. $D R C$ Sustainable Future. 2020; 1: 7-13.

Publisher Full Text

8. Pettit RE: Organic Matter, Humus, Humate, Humic Acid, Fulvic Acid and Humin: their Importance in Soil Fertility and Plant Health. 2008; 17. Corpus ID: 15995040 (Accessed: July 1, 2020.) Reference Source

9. Winkelbauer J, Völkel J, Leopold M, et al.: Methods of surveying the thickness of humous horizons using ground penetrating radar (GPR): an example from the Garmisch-Partenkirchen area of the Northern Alps. Eur J For Res. 2011; 130(5): 799-812 Publisher Full Text

10. Hoffmann S, Csitári G, Hegedüs L: The humus content and soil biological properties as a function of organic and mineral fertilization. Arch Agron Soil Sci. 2002; 48(2): 141-146. Publisher Full Text
11. Houba YJG, Novozamsky I, Temminghoff E: Soil anlysis procedures. Extraction with $0.01 \mathrm{M} \mathrm{CaCl} 2$ syllabus. Dept. of Soil Sci. and Plant Nutrition Wageningen Agricultural University-The Netherlands, 1994.

12. Jászberényi I, Loch J, Sarkadi J: Experiences of $0.01 \mathrm{M}$ calcium chloride extraction as soil testing procedure in Hungary Commun. Soil Sci Plant Anal. 1994; 25(9-10): 1771-1777.

Publisher Full Text

13. Standard: MSZ 080202: Hungarian Standards Institution. Budapest, Hungary. 2002.

14. Dövényi $Z$, Ambrózy $P$, Juhász Á, et al.: Magyarország kistájainak katasztere (Inventory of Microregions in Hungary). Retrived 30 Sept, 2020. 2008. Reference Source

15. Klimes-Szmik A: A talajok fizikai tulajdonságainak vizsgálata. Talaj és trágyvizsgálati módszerek.1970; (48): 83-161.

16. Standard: MSZ-08 0206/1-78: Hungarian Standards Institution. Budapest, Hungary. 1978.

17. Buzás I: A talajok fizikai-kémiai és kémiai vizsgálati módszerei (Physico chemical and chemical analysis methods of soils). Mezőgazdasági Kiadó, Budapest.1988. Reference Source

18. Székely Á: Talaj-és agrokémiai vizsgálati módszerek 2. Mezogazdasági kiadó, $1988 ; 115$.

Reference Source

19. Standard: MSZ-08-0210-77: Determination of soil organic carbon. In orginal language: "A talaj szerves szén tartalmának meghatározása." Magyar Szabványügyi Hivatal, Budapest MSZH- Nyomda, 1977; 6.

20. Standard: MSZ 20135: Hungarian Standards Institution. Budapest, Hungary Magyar Szabványügyi Hivatal, Budapest MSZH- Nyomda. 1999.

21. Berényi $S$, Bertáné Szabó $E$, Pepó $P$, et al:: Effect of fertilization and irrigation on $\mathbf{N}$ fractions determined in $\mathbf{0 . 0 1} \mathrm{M}$ calcium chloride on lowland pseudomyceliar chernozem. Agrokémia és Talajtan. 2009 ; 58(2): 251-264. Publisher Full Text

22. Dama Research Center limited: Supporting data - $\mathbf{N}$ forms and Humus\% in Sand soil, Nyírség. figshare. Dataset. 2020.

http://www.doi.org/10.6084/m9.figshare.12581303.v3 


\section{Open Peer Review}

\section{Current Peer Review Status:}

\section{Version 2}

Reviewer Report 23 October 2020

https://doi.org/10.5256/f1000research.29978.r72580

(C) $\mathbf{2 0 2 0}$ Kong Y. This is an open access peer review report distributed under the terms of the Creative Commons Attribution License, which permits unrestricted use, distribution, and reproduction in any medium, provided the original work is properly cited.

\section{Yuhua Kong}

College of Forestry, Henan Agricultural University, Zhengzhou, China

Competing Interests: No competing interests were disclosed.

Reviewer Expertise: Carbon and nitrogen cycles in terrestrial ecosystems

I confirm that I have read this submission and believe that I have an appropriate level of expertise to confirm that it is of an acceptable scientific standard.

Reviewer Report 14 October 2020

https://doi.org/10.5256/f1000research.29978.r72581

(C) 2020 Juhos $\mathbf{K}$. This is an open access peer review report distributed under the terms of the Creative Commons Attribution License, which permits unrestricted use, distribution, and reproduction in any medium, provided the original work is properly cited.

\section{Katalin Juhos}

Department of Agro-Environmental Studies, Szent István University, Budapest, Hungary

I have no further comments to make.

Competing Interests: No competing interests were disclosed.

Reviewer Expertise: soil quality, nutrient management

I confirm that I have read this submission and believe that I have an appropriate level of expertise to confirm that it is of an acceptable scientific standard. 
Reviewer Report 07 October 2020

https://doi.org/10.5256/f1000research.29978.r72582

(c) 2020 Agachi P. This is an open access peer review report distributed under the terms of the Creative Commons Attribution License, which permits unrestricted use, distribution, and reproduction in any medium, provided the original work is properly cited.

\section{Paul S. Agachi}

Department of Chemical, Materials and Metallurgical Engineering, Faculty of Engineering and Technology, Botswana International University of Science and Technology, Palapye, Botswana Agree with the changes, approve for indexing.

Competing Interests: No competing interests were disclosed.

Reviewer Expertise: Chemical engineering, clean coal technology, process control, modeling, optimization.

I confirm that I have read this submission and believe that I have an appropriate level of expertise to confirm that it is of an acceptable scientific standard.

\section{Version 1}

Reviewer Report 29 September 2020

https://doi.org/10.5256/f1000research.27875.r71958

(c) 2020 Agachi P. This is an open access peer review report distributed under the terms of the Creative Commons Attribution License, which permits unrestricted use, distribution, and reproduction in any medium, provided the original work is properly cited.

\section{Paul S. Agachi}

Department of Chemical, Materials and Metallurgical Engineering, Faculty of Engineering and Technology, Botswana International University of Science and Technology, Palapye, Botswana

The paper deals with the assessment of the appropriation of the sandy Pallag soil for raising crops, due to the humus and Nitrogen content. The ratio of nitrate- $\mathrm{N}$ and nitrite- $\mathrm{N}$ recommends the soil for crops.

The importance of this study is given mainly by the fact it is done on experimental plots, in real conditions.

My objections are related to the transparency of the Equations 1 and 2. Additional explanations 
should be added. Why the authors calculated this way the organic and the humus \%? The values of the constants should be explained. Maybe they are known for the category of the soil scientists, but for larger dissemination and understanding, additional explanations are needed.

Is the work clearly and accurately presented and does it cite the current literature? Yes

Is the study design appropriate and is the work technically sound?

Yes

Are sufficient details of methods and analysis provided to allow replication by others? Partly

If applicable, is the statistical analysis and its interpretation appropriate? Partly

Are all the source data underlying the results available to ensure full reproducibility? Yes

Are the conclusions drawn adequately supported by the results? Yes

Competing Interests: No competing interests were disclosed.

Reviewer Expertise: Chemical engineering, clean coal technology, process control, modeling, optimization.

I confirm that I have read this submission and believe that I have an appropriate level of expertise to confirm that it is of an acceptable scientific standard, however I have significant reservations, as outlined above.

Reviewer Report 18 September 2020

https://doi.org/10.5256/f1000research.27875.r70069

(C) 2020 Kong Y. This is an open access peer review report distributed under the terms of the Creative Commons Attribution License, which permits unrestricted use, distribution, and reproduction in any medium, provided the original work is properly cited.

\section{Yuhua Kong}

College of Forestry, Henan Agricultural University, Zhengzhou, China

The purpose and significance of the study are not very clear and lack of novelty.

The basic information of sampling site is not mentioned, like land-use type, the mean annual precipitation and air temperature, etc. 
How many replicates were carried out in the study? In table 1, the standard deviation should be included.

It is suggested that the Pearson correlation analysis between soil humus and all nitrogen forms be shown in the results part.

Is the work clearly and accurately presented and does it cite the current literature? Partly

Is the study design appropriate and is the work technically sound? Partly

Are sufficient details of methods and analysis provided to allow replication by others? Yes

If applicable, is the statistical analysis and its interpretation appropriate? Yes

Are all the source data underlying the results available to ensure full reproducibility? Yes

Are the conclusions drawn adequately supported by the results? Partly

Competing Interests: No competing interests were disclosed.

Reviewer Expertise: Carbon and nitrogen cycles in terrestrial ecosystems

I confirm that I have read this submission and believe that I have an appropriate level of expertise to confirm that it is of an acceptable scientific standard, however I have significant reservations, as outlined above.

Reviewer Report 24 August 2020

https://doi.org/10.5256/f1000research.27875.r69180

(C) 2020 Juhos $\mathbf{K}$. This is an open access peer review report distributed under the terms of the Creative Commons Attribution License, which permits unrestricted use, distribution, and reproduction in any medium, provided the original work is properly cited.

\section{Katalin Juhos}

Department of Agro-Environmental Studies, Szent István University, Budapest, Hungary

The purpose of the manuscript is not entirely clear:

Exactly what land-use type the samples come from (what do control and greenhouse mean? 
I don't see the comparison in the results section.)

What do you mean by "pollutant nitrogen" (= nitrite?)?

On the basis of the soluble $\mathrm{N}$-forms measured once in the upper $20 \mathrm{~cm}$ layer, how can it be concluded that the test soil is suitable for use? Soluble $\mathrm{N}$-forms change very rapidly in soil. $\mathrm{N}$-test methods are up-to-date, but it is not clear what soil-liquid ratio was used for $\mathrm{CaCl}_{2}$ and $\mathrm{KCl}$ extracts? Nor is it clear how many soil samples were tested?

The detailed determination of soluble $\mathrm{N}$-forms is very important. It would have been interesting to see this in the deeper layers of the soil as well. Furthermore, based on the total (Kjeldahl) $\mathrm{N}$ content of the soil, a picture of the source of soluble components could be obtained. Did the total soluble $\mathrm{N}$ content not correlate with SOM?

"Soil organic matter (SOM)" is proposed instead of "Humus" and "soil organic carbon (SOC)" is proposed instead of "C\%".

In the description of the SOM method, $\mathrm{K} 2 \mathrm{SO} 4$ is erroneously used instead of K-dichromate. When giving the averages, the number of items and the standard deviation must also be included (Table 1).

Is the work clearly and accurately presented and does it cite the current literature? Partly

Is the study design appropriate and is the work technically sound? Partly

Are sufficient details of methods and analysis provided to allow replication by others? Partly

If applicable, is the statistical analysis and its interpretation appropriate? Partly

Are all the source data underlying the results available to ensure full reproducibility? Partly

Are the conclusions drawn adequately supported by the results?

Partly

Competing Interests: No competing interests were disclosed.

Reviewer Expertise: soil quality, nutrient management

I confirm that I have read this submission and believe that I have an appropriate level of expertise to confirm that it is of an acceptable scientific standard, however I have significant reservations, as outlined above. 
The benefits of publishing with F1000Research:

- Your article is published within days, with no editorial bias

- You can publish traditional articles, null/negative results, case reports, data notes and more

- The peer review process is transparent and collaborative

- Your article is indexed in PubMed after passing peer review

- Dedicated customer support at every stage

For pre-submission enquiries, contact research@f1000.com 